\title{
The association of bone mineral density and parathyroid hormone with serum magnesium in adult patients with sickle-cell anaemia
}

\author{
Mohamed F. Elshal ${ }^{1,2}$, Amna E. Bernawi ${ }^{1}$, Maryam A. Al-Ghamdy', Jalaluddin A. Jalal ${ }^{1}$
}

1Biochemistry Department, Faculty of Science, King Abdulaziz University, Jeddah, Kingdom of Saudi Arabia

2Molecular Biology Department, Genetic Engineering and Biotechnology Research Institute, Menoufiya University, Egypt

Submitted: 17 December 2010

Accepted: 11 June 2011

Arch Med Sci 2012; 8, 2: 270-276

DOI: 10.5114 /aoms.2012.28554

Copyright @ 2012 Termedia \& Banach

\section{Abstract}

Introduction: Bone disorders including osteopenia and osteoporosis are a frequent cause of morbidity in sickle-cell disease (SCD). Magnesium (Mg) regulates some biological processes important in bone remodelling. We aimed to investigate whether serum $\mathrm{Mg}$ levels (sMg) may have an impact on bone mineral density (BMD) in sickle-cell anaemia (SCA).

Material and methods: Sixty adults with SCA in steady-state and 20 age- and race-matched healthy blood donors were included in the study. The BMD was evaluated with respect to minerals and biochemical indices of bone metabolism. Multivariate analysis was performed to determine the factors influencing BMD. Results: The mean $\mathrm{sMg}$ concentration was $0.64 \pm 0.06$ (reference range $0.7-1.2 \mathrm{mmol} / \mathrm{l}$ ) for $34 \%$ of the population, and $0.86 \pm 0.08 \mathrm{mmol} / \mathrm{l}$ for $66 \%$. There were significant differences between $\mathrm{Mg}$ groups and controls in $\mathrm{BMD}$, phosphorus $\left(\mathrm{PO}_{4}\right)$, parathyroid hormone (PTH) $(p=0.011, p=0.011$ and $p=0.0001$ respectively) and osteocalcin (OC) $(p=0.030)$ levels. The $\mathrm{sMg}$ was found to be associated positively with serum calcium (Ca), PTH and OC $(r=0.585 ; r=0.436 ; r=0.351$ respectively, all at $p<0.05)$, and negatively with $\mathrm{PO}_{4}(r=-0.312 ; p<0.05)$. Multivariate analysis demonstrated that only PTH $(p<0.05)$ was an independent factor for BMD. Moreover, it identified SMg, OC, and CTX as independent factors for PTH (all $p<0.05$ ).

Conclusions: These results indicate that serum $\mathrm{Mg}$ may be a co-contributing factor in causing low BMD. However, other possible aetiologies including decreased PTH and increased bone turnover certainly play a role. Based on the present data, it is prudent to monitor $\mathrm{sMg}$ routinely in this patient population and treat the condition whenever possible.

Key words: sickle-cell anaemia, magnesium, calcium, bone mineral density, parathyroid hormone, osteoporosis, bone turnover.

\section{Introduction}

Sickle-cell disease (SCD) is an autosomal recessive genetic disease with an increase in the adhesion of sickled erythrocytes, and it is a potential cause of vaso-occlusive episodes, which are related to clinical manifestations, morbidity and mortality [1, 2]. The SCA often coincides with osteoporosis or osteopenia in children and young adults [3]. Accumulated evidence suggests that tissue injury and adverse effects on bone are usually produced by increased erythropoiesis and hypoxic conditions secondary

\author{
Corresponding author: \\ Mohamed F. Elshal MD, PhD \\ Biochemistry Department \\ Faculty of Science \\ King Abdulaziz \\ University Jeddah \\ Kingdom of Saudi Arabia \\ Phone: 00966542028446 \\ Fax: 00966026952288 \\ E-mail: \\ Melshal2002@yahoo.com
}


to the obstruction of blood vessels by sickled erythrocytes [4, 5].

Magnesium (Mg) plays an important role in the pathophysiology of erythrocyte sickling in SCA [6]. Magnesium has also been shown to slow clotting time $[7,8]$, which might reduce vascular blockage and improve blood flow in SCD. Clinical studies showed that Mg deficiency, which is partially due to increased urinary $\mathrm{Mg}$ excretion [9], induces dehydration and morphological abnormalities in erythrocytes, promotes vasoconstriction and enhances vascular endothelial injury, leading to hypoxia in multiple organs including the osseous tissue [10]. Additionally, $\mathrm{Mg}$ regulates biological processes important in bone remodelling such as calcium absorption, parathyroid hormone (PTH) secretion, osteoblast adhesion and bone formation [11-13]. The Mg deficiency produces hormonal and skeletal disturbances that have been associated with a number of bone disorders including osteoporosis $[14,15]$. This has been supported by experimental magnesium deficiency studies showing that insufficient dietary Mg intake increased osteoclast number, and bone loss in laboratory animals [16].

This does not appear to have been studied in patients with sickle-cell anaemia and this prompted us to assess the prevalence of $\mathrm{Mg}$ deficiency in a group of adult patients with SCD, and to analyse the relationships between bone turnover markers with serum $\mathrm{Mg}$ to determine the role of $\mathrm{Mg}$ in the pathogenesis of bone changes seen in SCD.

\section{Material and methods}

\section{Subjects}

Adult patients with steady state SCD within the age range 20-40 years visiting the outpatient clinic of the university hospital were asked to participate in the study. Twenty age and race matched HbAA healthy blood donors were enrolled in the study as the control group. Ethical approval was obtained from the research and scientific committee of the university. Informed consent was obtained from all participants after explanation of the nature of the study. History was taken and clinical examination was done and followed by appropriate investigations to rule out any secondary disorders that might be causing osteoporosis. Patients who were on steroids, had anorexia nervosa, hyperthyroidism, chronic obstructive pulmonary disease, liver disease, inflammatory bowel disease, or had deranged renal functions (serum creatinine $>2.5 \mathrm{mg} / \mathrm{dl}$ ) were excluded from the study.

\section{Bone mineral density measurements}

Bone mineral density (BMD) and T-score analyses were done at lumbar spine L2, lumbar spine L4 and total body BMD twice by dual-energy $\mathrm{X}$-ray absorptiometry (DXA) imaging (Hologic QDR 2000, Bedford, MA). T-scores are standard deviations of patient BMD compared with BMD of young, healthy, sex-matched adult controls. T-score values were calculated based on data of young adults aged 20-40 years [17]. Cases studied were classified as osteoporosis when T-score was $\leq 2.5$ and osteopenia when T-score was between -1.0 and -2.5 at one or more anatomical sites, consistent with WHO criteria [18].

\section{Biochemical tests}

All blood samples were collected at 10 am after overnight fasting. Serum samples were separated by centrifugation at $3000 \mathrm{rpm}$ for $10 \mathrm{~min}$, and then were stored in the freezer at $-80^{\circ} \mathrm{C}$ until analysis. Serum calcium (Ca), magnesium ( $\mathrm{Mg}$ ) and phosphate $\left(\mathrm{PO}_{4}\right)$ were measured using an endpoint assay in a Dade Behring Dimension RxL clinical chemistry system (Dade Behring; Germany) using standard procedures [19]. Total calcium concentration was adjusted for serum albumin. The laboratory reference ranges are 2.2-2.6 $\mathrm{mmol} / \mathrm{l}$ for $\mathrm{Ca}$, 0.8-1.2 mmol/l for $\mathrm{Mg}$, and 1.0-1.4 mmol// for $\mathrm{PO}_{4}$.

Intact serum parathyroid hormone (iPTH) levels were measured by electrochemiluminescence immunoassay (Roche Diagnostics, Germany) [20]. The reference range for iPTH was $15-65 \mathrm{pg} / \mathrm{ml}$ (1.6-6.9 pmol/l), with analytical sensitivity of < 0.1 $\mathrm{pmol} / \mathrm{I}$ and intra- and inter-assay CV (coefficient of variation) values less than $5 \%$ and $7 \%$, respectively. Serum b-ALP was detected using an EIA kit (OSTASE ${ }^{\circledR}$ Bone Specific Alkaline Phosphatase EIA, Immunodiagnostic Systems Inc, Fountain Hills, AZ, USA) [21]. Analytical sensitivity for the b-ALP assay was $<1 \mathrm{U} / \mathrm{l}$ (reference range between $50 \mathrm{U} / \mathrm{l}$ and $136 \mathrm{U} / \mathrm{l})$ with an intra- and inter-assay variability lower than $10.1 \%$ and $10 \%$, respectively. Serum intact OC level was assessed by a solid-phase enzyme-amplified sensitivity immunoassay kit (hOST-EASIA; BioSource Europe S.A., Nivelles, Belgium). This immunoassay is specific for measurement of intact form of osteocalcin with proven absence of cross reactivity with other osteocalcin fragments [22]. Analytical sensitivity was $<0.4 \mathrm{ng} /$ $\mathrm{ml}$ (reference range between $6.8 \mathrm{ng} / \mathrm{ml}$ and $32.2 \mathrm{ng}$ / $\mathrm{ml}$ ) with intra- and inter-assay CV values of $5.2 \%$ and $6.7 \%$ respectively. The serum marker of bone resorption C-terminal telopeptide of type-I collagen (CTX) was measured by a two-site ELISA (Serum Crosslaps one-step; Osteometer Biotech, A/S, Denmark). The reference range is between $0.13 \mathrm{ng} / \mathrm{ml}$ and $4.1 \mathrm{ng} / \mathrm{ml}$ and intra- and inter-assay CV of the assay is $5.2 \%$ and $6.7 \%$. Serum N-terminal telopeptide of type-I collagen (NTx), a specific biochemical indicator of bone resorption, was measured using an enzyme immunoassay (Osteomark ${ }^{\circledR}$ Wampole Laboratories Inc., Princeton, NJ, USA) with detec- 
Table I. Characteristics and laboratory data of healthy controls and SCD patients

\begin{tabular}{|lccl|}
\hline Parameter & $\begin{array}{c}\text { SCD Group } \\
(n=60)\end{array}$ & $\begin{array}{c}\text { Control group } \\
(n=20)\end{array}$ & Value of $p$ \\
\hline Age $[$ years $]$ & $22.37 \pm 7.40$ & $22.87 \pm 4.91$ & 0.631 \\
\hline $\mathrm{Mg}[\mathrm{mmol} / \mathrm{l}]$ & $0.74 \pm 0.14$ & $0.85 \pm 0.17$ & 0.044 \\
\hline $\mathrm{Ca}[\mathrm{mmol} / \mathrm{l}]$ & $2.11 \pm 0.13$ & $2.36 \pm 0.19$ & 0.022 \\
\hline $\mathrm{PO}_{4}[\mathrm{mmol} / \mathrm{l}]$ & $1.32 \pm 0.25$ & $1.14 \pm 0.23$ & 0.006 \\
\hline $\mathrm{PTH}[\mathrm{pmol} / \mathrm{l}]$ & $2.22 \pm 1.26$ & $4.11 \pm 1.46$ & 0.0001 \\
\hline b-ALP $[\mathrm{U} / \mathrm{l}]$ & $77.13 \pm 14.81$ & $59.69 \pm 12.57$ & 0.021 \\
\hline OC $[\mathrm{ng} / \mathrm{ml}]$ & $56.46 \pm 5.3$ & $37.88 \pm 6.53$ & 0.001 \\
\hline CTX $[\mathrm{ng} / \mathrm{ml}]$ & $0.41 \pm 0.16$ & $0.36 \pm 0.16$ & 0.017 \\
\hline NTX $[\mathrm{ng} / \mathrm{ml}]$ & $1.06 \pm 0.41$ & $0.97 \pm 0.36$ & 0.383 \\
\hline
\end{tabular}

Mean $\pm S D, M g-$ magnesium, $\mathrm{Ca}$ - calcium, $\mathrm{PO}_{4}$ - phosphate, $b$-ALP - bone-specific alkaline phosphatase, OC - total osteocalcin, CTX-I - C-terminal telopeptide of type-I collagen, NTX - N-terminal telopeptide of type-I collagen

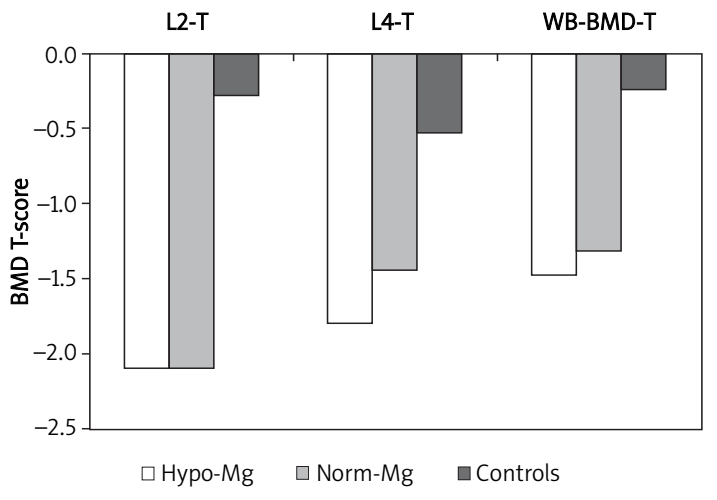

Figure 1. Bone mineral density T-score according to magnesium levels. ANOVA test revealed significant variation between groups at L2, L4 and WB-BMD ( $p<0.001, p<0.05$ and $p<0.001$ respectively)

tion limit of $2.5 \mathrm{nM}$ bone collagen equivalent (BCE) (reference range: $10 \mathrm{nM}$ to $60 \mathrm{nM} \mathrm{BCE}$ ), and $\mathrm{CV}$ equal to $4.6 \%[22]$.

\section{Statistical analysis}

Results were expressed as mean \pm standard deviation. $\chi^{2}$ tests, ANOVA, and non-parametric tests for trend were used, as appropriate, to compare the proportion of patients with specified clinical characteristics. When significant differences were observed in ANOVA, Bonferroni post-hoc testing was done to identify differences between groups. Correlation analysis was done using linear regression and Pearson's correlation coefficient. Statistical significance was defined by a $p<0.05$. All statistical tests were two-tailed. A sample size analysis demonstrated that 19 subjects would be required in each group to detect a statistically significant $(p<0.05)$ difference of 0.05 in serum magnesium level between groups (SD, 0.05; power,
88\%). Calculations were done using SPSS for Windows (release 13.0, 2004; SPSS Inc., Chicago, IL).

\section{Results}

Sixty SCA patients, confirmed by previous haemoglobin electrophoresis and/or HPLC, were included in the study. The mean age of patients was 24.64 ( \pm 4.26 ) years ( 34 females and 26 males). The control group included 20 age-matched $(26.73 \pm 5.84$ years old) subjects ( 22 females and 18 males). The $\chi^{2}$ analysis showed no significant differences between patients and control groups regarding age $\left(\chi^{2}=0.33, p>0.05\right)$ or $\operatorname{sex}\left(\chi^{2}=0.64, p>0.05\right)$.

According to WHO criteria using T scores, 43 patients (71\%) were osteoporotic or osteopenic at least in one of the three studied anatomical locations. The SCA patients showed significantly lower BMD T-score at L2, L4 and WB-BMD in comparison with controls $(p=0.002 ; p=0.035$; and $p=0.008$ respectively). There was a significant decrease of serum Ca $(p=0.022)$ and serum PTH $(p<0.0001)$, and a significant increase in serum $\mathrm{PO}_{4}(p=0.006)$ in the patient group compared to the control group. Significant increases in b-ALP, OC, and CTX levels were also found in SCA patients compared to controls ( $p=0.021, p=0.001, p=0.017$ respectively); however, serum NTX demonstrated no significant change between groups (Table I).

To determine the impact of $\mathrm{Mg}$ deficiency in this group of SCA patients on other minerals, hormonal, and bone turnover markers, patients were divided according to their serum $\mathrm{Mg}$ concentrations into hypomagnesaemic $(\mathrm{Mg}<0.7 \mathrm{mmol} / \mathrm{l})$ and normomagnesaemic ( $\mathrm{Mg} \geq 0.7 \mathrm{mmol} / \mathrm{l})$, and these parameters were compared to those of controls. Twenty patients (33.3\%) had serum Mg levels lower than the normal range $(0.7-1.2 \mathrm{mmol} / \mathrm{l})$. These hypo-Mg patients had significantly lower $B M D$ and $T$-score at all evaluated sites $(L 2, L 4$, and WB) than norm-Mg patients and controls (all $p<0.05)$ (Figure 1). Hypo-Mg patients showed lower $\mathrm{Ca}(p<0.001)$ and PTH $(p<0.001)$ concentrations compared with norm-Mg patients and controls. Analyses of biochemical bone marker data showed that hypo-Mg SCA patients had significantly higher $\mathrm{PO}_{4}, \mathrm{~b}-\mathrm{ALP}$ and OC concentrations in comparison to norm-Mg and controls $(p<0.05$; $p<0.05$ respectively). Serum CTx, and NTx concentrations were not significantly different between studied groups by ANOVA analysis; however, CTX levels were significantly higher in the hypo-Mg than the norm-Mg group according to the post-hoc Bonferroni test $(p<0.05)$.

Table III presents the univariate Pearson correlations between the studied parameters. Serum Mg showed significant positive correlations with $\mathrm{Ca}$ $(r=0.736, p<0.000)$, PTH $(r=0.446, p<0.05)$, and OC $(r=0.358, p<0.05)$, and a significant negative 
Table II. Comparison of studied parameters between controls and sickle-cell patients classified according to magnesium status

\begin{tabular}{|c|c|c|c|c|c|}
\hline \multirow[t]{2}{*}{ Parameter } & \multicolumn{2}{|c|}{ SCD patients } & \multirow{2}{*}{$\begin{array}{l}\text { Control group } \\
\quad(n=20)\end{array}$} & \multicolumn{2}{|c|}{ ANOVA } \\
\hline & Hypo-Mga $(n=20)$ & Norm-Mgb $(n=40)$ & & $\mathrm{F}$ & Sig. \\
\hline Age [years] & $23.40 \pm 3.58$ & $21.40 \pm 6.09$ & $22.87 \pm 4.91$ & 1.156 & 0.506 \\
\hline $\mathrm{Mg}[\mathrm{mmol} / \mathrm{l}]$ & $0.64 \pm 0.06^{c, d}$ & $0.86 \pm 0.08$ & $0.85 \pm 0.17$ & 17.669 & 0.0001 \\
\hline $\mathrm{Ca}[\mathrm{mmol} / \mathrm{l}]$ & $2.04 \pm 0.34 c, d$ & $2.33 \pm 0.25$ & $2.36 \pm 0.19$ & 1.716 & 0.197 \\
\hline $\mathrm{PO}_{4}[\mathrm{mmol} / \mathrm{l}]$ & $1.23 \pm 0.32$ & $1.28 \pm 0.27$ & $1.14 \pm 0.23$ & 4.963 & 0.011 \\
\hline PTH [ng/l] & $2.22 \pm 0.95$ & $2.20 \pm 1.34$ & $4.11 \pm 1.46$ & 8.604 & 0.001 \\
\hline b-ALP [U/I] & $66.82 \pm 11.41$ & $81.10 \pm 13.91$ & $59.69 \pm 12.57$ & 5.210 & 0.011 \\
\hline $\mathrm{OC}[\mathrm{ng} / \mathrm{ml}]$ & $47.40 \pm 7.92$ & $60.07 \pm 13.75$ & $37.88 \pm 6.53$ & 9.543 & 0.001 \\
\hline CTx [ng/ml] & $0.36 \pm 0.07 c$ & $0.43 \pm 0.18$ & $0.36 \pm 0.16$ & 1.180 & 0.120 \\
\hline NTx (nM BCE) & $0.92 \pm 0.43$ & $1.15 \pm 0.38$ & $0.97 \pm 0.36$ & 1.069 & 0.355 \\
\hline
\end{tabular}

ануро- $\mathrm{Mg}-\operatorname{serum~} \mathrm{Mg}<0.7 \mathrm{mmol} / \mathrm{l},{ }^{b} \mathrm{Norm}-\mathrm{Mg}-\operatorname{serum~} \mathrm{Mg}>0.7 \mathrm{mmol} / \mathrm{l}, \mathrm{c}_{p}<0.05$ in comparison to controls, ${ }_{p} p<0.05$ in comparison to hyperMg group

Table III. Univariate analyses of relationships between $\mathrm{Mg}$ and other markers of bone metabolism

\begin{tabular}{|lcccccccc|}
\hline \multirow{2}{*}{ Parameter } & \multicolumn{2}{c}{ BMD } & \multicolumn{2}{c}{ PTH } & \multicolumn{2}{c}{ Ca } & \multicolumn{2}{c|}{ Mg } \\
\cline { 2 - 10 } & $r^{\mathrm{a}}$ & Value of $p$ & $r$ & Value of $p$ & $r$ & Value of $p$ & $r$ & Value of $p$ \\
\hline BMD & 1.000 & - & $0.329^{b}$ & 0.042 & 0.211 & 0.300 & 0.209 & 0.286 \\
\hline PTH & $0.329^{b}$ & 0.042 & 1.000 & - & 0.231 & 0.247 & $0.446^{b}$ & 0.022 \\
\hline Ca & 0.211 & 0.300 & 0.231 & 0.247 & 1.000 & - & $0.736^{b}$ & 0.0001 \\
\hline Mg & 0.209 & 0.286 & $0.446^{b}$ & 0.022 & $0.736^{b}$ & 0.000 & 1.000 & - \\
\hline PO 4 & $-0.397^{b}$ & 0.030 & 0.043 & 0.828 & $0.390^{b}$ & 0.032 & $-0.342^{b}$ & -0.022 \\
\hline b-ALP & 0.010 & 0.957 & 0.152 & 0.441 & 0.269 & 0.167 & 0.049 & 0.641 \\
\hline OC & $-0.378^{b}$ & 0.044 & $-0.550^{b}$ & 0.002 & 0.060 & 0.761 & $0.358^{b}$ & 0.031 \\
\hline CTX & -0.289 & 0.122 & $-0.379 b$ & 0.037 & -0.135 & 0.493 & 0.081 & 0.748 \\
\hline NTX & -0.097 & 0.610 & 0.083 & 0.674 & 0.268 & 0.168 & 0.103 & 0.631 \\
\hline
\end{tabular}

apearson correlation coefficient, ${ }^{b}$ Significant correlation (2-tailed)

correlation with serum $\mathrm{PO}_{4}(r=-0.312, p<0.05)$. The BMD showed a significant negative correlation with phosphorus and osteocalcin $(r=-0.397$, $p<0.05 ; r=-0.378, p<0.05$ respectively). The PTH correlated positively with BMD $(r=0.329, p<0.05)$, and $\mathrm{Mg}(r=0.446, p<0.05)$ and negatively correlated with OC $(r=0.550, p<0.001)$ and CTX $(r=0.343, p<0.05)$. Calcium showed a significant positive correlation with $\mathrm{Mg}(r=0.736, p<0.001)$ and $\mathrm{PO}_{4}(r=0.390, p<0.05)$.

Table IV summarizes the multivariate analysis of relationships between either BMD or PTH with other studied parameters. To elucidate the significant determinants of BMD, we performed a multiple regression analysis that used the serum $\mathrm{Ca}, \mathrm{PO}_{4}$, $\mathrm{Mg}, \mathrm{PTH}, \mathrm{OC}, \mathrm{b}-\mathrm{ALP}, \mathrm{CTX}$, and NTX as the potential explanatory variables. It was found that PTH was the only independent determinant of BMD $(p=0.039)$. Multiple linear regression analysis also showed Mg, OC and CTX as independent determinants of PTH (all $p<0.05$ ).
Table IV. Multivariate analysis of the relationships between BMD or PTH and other studied parameters

\begin{tabular}{|lcccc|}
\hline \multirow{2}{*}{ Parameter } & \multicolumn{2}{c}{ aDependent: BMD } & \multicolumn{2}{c|}{ bDependent: PTH } \\
\cline { 2 - 5 } & Coefficient & \multicolumn{3}{c|}{ Coefficient } \\
\hline BMD & - & - & 0.145 & 0.373 \\
\hline PTH & $0.413 c$ & 0.039 & - & - \\
\hline Ca & -0.055 & 0.792 & -0.062 & 0.784 \\
\hline Mg & 0.161 & 0.457 & $0.397 c$ & 0.012 \\
\hline PO ${ }_{4}$ & -0.288 & 0.133 & -0.123 & 0.407 \\
\hline OC & -0.123 & 0.601 & $0.403 c$ & 0.013 \\
\hline b-ALP & -0.026 & 0.895 & 0.013 & 0.94 \\
\hline CTX & -0.131 & 0.553 & $0.399 c$ & 0.013 \\
\hline NTX & -0.13 & 0.508 & 0.039 & 0.806 \\
\hline Age & 0.079 & 0.662 & -0.016 & 0.918 \\
\hline
\end{tabular}

a Dependent variable: BMD, predictor in the model: $\mathrm{PTH}$; ${ }^{b}$ dependent variable: $P T H$, predictors in the model: osteocalcin, magnesium, CTX; csignificant correlation 


\section{Discussion}

In the present study, patients with SCD showed significantly lower BMD concentration at L2, L4 and WB-BMD (all $p<0.05$ ) than the control group. Furthermore, $30 \%$ of the patients were found to be osteopenic and $50 \%$ osteoporotic based on T-scores of the patients according to WHO guidelines. These results are accompanied by a significant reduction in PTH and serum Ca concentrations and increased concentration of bone turnover parameters (OC, $\mathrm{b}-\mathrm{ALP}$ and (TX). These results are in accordance with those of previous literature $[1,23]$, and suggest a relation between low BMD and increased bone turnover, as previously reported [24].

It has been suggested that $\mathrm{Mg}$ deficiency may have a role in the development of osteoporosis [2527]. We therefore investigated whether alterations in $\mathrm{sMg}$ may have a role in the pathogenesis of bone changes seen in sickle-cell anaemia. In the present study, $\mathrm{Mg}$ levels were lower than the normal range (0.7-1.2 $\mathrm{mmol} / \mathrm{l})$ in $34 \%$ of SCA patients. These patients showed significantly lower BMD values and T-score than norm-Mg patients and controls. These findings suggest that Mg deficiency may have a role in the decreased BMD found in our group of patients with SCA.

We then studied the inter-relationships between sMg and bone turnover parameters OC, b-ALP, CTX and NTX. Osteocalcin and b-ALP are phenotypic markers for terminally differentiated osteoblasts and early-stage differentiated osteoblasts, respectively [28]. We found that b-ALP and OC are increased both in hypo- and norm-Mg patients compared with controls. These findings are in agreement with previous studies reporting accelerated bone turnover in SCA patients [29]. In addition, we found that CTX levels are increased significantly in hypomagnesaemic SCA patients compared to the control group, which reflects the increased bone resorption. Moreover, CTX was found to be negatively correlated with PTH by univariate correlation analysis, and an independent negative determinant of PTH by stepwise multiple regression analysis.

The PTH is very important for skeletal health. It is synthesized and secreted by the chief cells of the parathyroid glands and is the principal hormone responsible for calcium homeostasis [30]. We further found that the hypo-Mg group had significantly lower PTH levels than either norm-Mg or controls, and that serum Mg correlated positively with serum PTH. These patients showed significantly reduced BMD. In addition, multivariate analysis identified PTH as the only predictive factor for BMD. These data suggest that a blunted PTH response in hypo$\mathrm{Mg}$ patients may be the causative factor for BMD reduction in SCD. These results are supported by previous studies which suggested that $\mathrm{Mg}$ deficiency causes impairment of PTH release from the parathyroid and the refractoriness of bone and kidney to the hormone, which may lead to the suppression of bone remodelling [14, 25, 31, 32].

The reciprocal relationship between $\mathrm{Mg}$ and PTH is well documented [14]. Hypomagnesaemia appears to blunt the hypocalcaemic release of PTH [31], through the intermediary action of CAMP [33]. Magnesium is also required for the sensitivity of the target tissues to PTH and vitamin D metabolites [34, 35]. On the other hand, PTH has profound effects on $\mathrm{Mg}$ reabsorption in the kidney and gut and release from bone [36].

Another effect of PTH on the kidney is to stimulate loss of phosphate ions in urine by reducing the reabsorption of phosphate from the proximal tubule [37]. In the present study we found that PTH correlates negatively with $\mathrm{PO}_{4}(r=-0.321, p<0.031)$. Therefore, the decrease in PTH may explain the elevated serum $\mathrm{PO}_{4}$ observed in these patients. It has been reported that modest increases in serum $\mathrm{PO}_{4}$ levels significantly affect red cell metabolism, increase 2,3 diphosphoglycerate (DPG) levels, and cause decreased affinity of oxygen for haemoglobin. Such changes could lead to increased intravascular sickling and blood flow abnormalities [38], which have been associated with osteoporosis [23]. Moreover, low levels of total magnesium in sicklecell erythrocytes have been linked to increased sickling due to cell dehydration [39]. In the present study, $\mathrm{PO}_{4}$ was found to be negatively correlated with serum magnesium $(r=-0.342, p<0.022)$. These data suggest that increased serum $\mathrm{PO}_{4}$ along with decreased serum $\mathrm{Mg}$ could represent additional pathogenic mechanisms contributing, in these cases, to low BMD.

In conclusion, we identified a group of SCD patients with reduced serum $\mathrm{Mg}$ levels, who had significantly lower BMD than their counterparts with normal Mg concentrations, suggesting that serum Mg may play an important role in bone metabolism through its association with $\mathrm{PTH}, \mathrm{OC}$ and $\mathrm{PO}_{4}$, and may provide additional information for the pathogenesis of bone loss in this disease. Finally, the present data warrant further investigation to determine whether serum $\mathrm{Ca} / \mathrm{PO}_{4}$ and PTH values normalize in SCA patients with $\mathrm{Mg}$ repletion in a prospective way, which will be an important and cost-effective intervention in this group of patients.

\section{References}

1. Gupta R, Marouf R, Adekile A. Pattern of bone mineral density in sickle cell disease patients with the high-Hb f phenotype. Acta Haematol 2010; 123: 64-70.

2. Sarrai M, Duroseau H, D'Augustine J, Moktan S, Bellevue R. Bone mass density in adults with sickle cell disease. $\mathrm{Br}$ J Haematol 2007; 136: 666-72. 
3. Miller RG, Segal JB, Ashar BH, et al. High prevalence and correlates of low bone mineral density in young adults with sickle cell disease. Am J Hematol 2006; 81: 236-41.

4. Kaul DK, Fabry ME, Nagel RL. The pathophysiology of vascular obstruction in the sickle syndromes. Blood Rev 1996; 10: 29-44.

5. Laroche M, Ludot I, Brousset P, Mazieres B. Osteoporosis with lymphoid nodules and hematopoietic marrow hyperplasia. Clin Exp Rheumatol 1999; 17: 457-60.

6. Olukoga AO, Adewoye HO, Erasmus RT, Adedoyin MA. Erythrocyte and plasma magnesium in sickle-cell anaemia. East Afr Med J 1990; 67: 348-54.

7. Assaley J, Baron JM, Cibils LA. Effects of magnesium sulfate infusion upon clotting parameters in patients with pre-eclampsia. J Perinat Med 1998; 26: 115-9.

8. Huntsman RG, Hurn BA, Lehmann H. Observations on the effect of magnesium on blood coagulation. J Clin Pathol 1960; 13: 99-101.

9. Olukoga AO, Adewoye HO, Erasmus RT, Adedoyin MA. Urinary magnesium excretion in steady-state sickle cell anaemia. Acta Haematol 1993; 90: 136-8.

10. De Franceschi L, Brugnara C, Rouyer-Fessard P, Jouault H, Beuzard Y. Formation of dense erythrocytes in sad mice exposed to chronic hypoxia: evaluation of different therapeutic regimens and of a combination of oral clotrimazole and magnesium therapies. Blood 1999; 94 : 4307-13.

11. Chou HF, Schwartz R, Krook L, Wasserman RH. Intestinal calcium absorption and bone morphology in magnesium deficient chicks. Cornell Vet 1979; 69: 88-103.

12. Sader MS, Legeros RZ, Soares GA. Human osteoblasts adhesion and proliferation on magnesium-substituted tricalcium phosphate dense tablets. J Mater Sci Mater Med 2009; 20: 521-7.

13. Wallach S. Effects of magnesium on skeletal metabolism. Magnes Trace Elem 1990; 9: 1-14.

14. Kanazawa I, Yamamoto M, Yamaguchi T, Yamauchi $M$, Yano S, Sugimoto T. A case of magnesium deficiency associated with insufficient parathyroid hormone action and severe osteoporosis. Endocr J 2007; 54: 935-40.

15. Rude RK, Gruber HE, Norton HJ, Wei LY, Frausto A, Kilburn J. Reduction of dietary magnesium by only $50 \%$ in the rat disrupts bone and mineral metabolism. Osteoporos Int 2006; 17: 1022-32.

16. Rude RK, Singer FR, Gruber HE. Skeletal and hormonal effects of magnesium deficiency. J Am Coll Nutr 2009; 28: 131-41.

17. Shepherd JA, Meta M, Landau J, et al. Metacarpal index and bone mineral density in healthy African-American women. Osteoporos Int 2005; 16: 1621-6.

18. WHO Study Group on Assessment of Fracture Risk and its Application to Screening for Postmenopausal Osteoporosis, World Health Organization. Assessment of fracture risk and its application to screening for postmenopausal osteoporosis. Report of a WHO study group [meeting held in Rome from 22 to 25 June 1992] Geneva, World Health Organization, 1994.

19. Cuka S, Dvornik S, Drazenovic K, Mihic J. Evaluation of the dade behring dimension rxl clinical chemistry analyzer. Clin Lab 2001; 47: 35-40.

20. Wan B, Augustin R, Chan MK, Leblond J, Verjee Z, Adeli K. Analytical performance and workflow evaluation of the roche e170 modular immunoassay analyzer in a pediatric setting. Clin Biochem 2005; 38: 262-71.

21. Broyles DL, Nielsen RG, Bussett EM, et al. Analytical and clinical performance characteristics of tandem-mp ostase, a new immunoassay for serum bone alkaline phosphatase. Clin Chem 1998; 44: 2139-47.
22. Schmidt-Gayk H, Spanuth E, Kotting J, et al. Performance evaluation of automated assays for beta-crosslaps, n-midosteocalcin and intact parathyroid hormone (biorose multicenter study). Clin Chem Lab Med 2004; 42: 90-5.

23. Tantawy AAG, El-Bostany EA, Matter RM, El-Ghoroury EA, Ragab S. Predictors of bone disease in Egyptian prepubertal children with -thalassaemia major. Arch Med Sci 2010; 6: 584-91.

24. Buchowski MS, de la Fuente FA, Flakoll PJ, Chen KY, Turner EA. Increased bone turnover is associated with protein and energy metabolism in adolescents with sickle cell anemia. Am J Physiol Endocrinol Metab 2001; 280: E518-27.

25. Sahota O, Mundey MK, San P, Godber IM, Hosking DJ. Vitamin $D$ insufficiency and the blunted pth response in established osteoporosis: the role of magnesium deficiency. Osteoporos Int 2006; 17: 1013-21.

26. Reginster JY, Strause L, Deroisy R, Lecart MP, Saltman P, Franchimont P. Preliminary report of decreased serum magnesium in postmenopausal osteoporosis. Magnesium 1989; 8: 106-9.

27. Rude RK, Olerich M. Magnesium deficiency: possible role in osteoporosis associated with gluten-sensitive enteropathy. Osteoporos Int 1996; 6: 453-61.

28. Nakashima K, de Crombrugghe B. Transcriptional mechanisms in osteoblast differentiation and bone formation. Trends Genet 2003; 19: 458-66.

29. Fung EB, Kawchak DA, Zemel BS, Rovner AJ, OheneFrempong K, Stallings VA. Markers of bone turnover are associated with growth and development in young subjects with sickle cell anemia. Pediatr Blood Cancer 2008; 50: 620-3.

30. Parfitt AM. The actions of parathyroid hormone on bone: Relation to bone remodeling and turnover, calcium homeostasis, and metabolic bone disease. Part i of iv parts: mechanisms of calcium transfer between blood and bone and their cellular basis: morphological and kinetic approaches to bone turnover. Metabolism 1976; 25: 809-44.

31. Klein GL, Nicolai M, Langman CB, Cuneo BF, Sailer DE, Herndon DN. Dysregulation of calcium homeostasis after severe burn injury in children: possible role of magnesium depletion. J Pediatr 1997; 131: 246-51.

32. Suh SM, Tashjian AH Jr, Matsuo N, Parkinson DK, Fraser D. Pathogenesis of hypocalcemia in primary hypomagnesemia: normal end-organ responsiveness to parathyroid hormone, impaired parathyroid gland function. J Clin Invest 1973; 52: 153-60.

33. Abou-Samra AB, Zajac JD, Schiffer-Alberts D, et al. Cyclic adenosine 3',5'-monophosphate (camp)-dependent and camp-independent regulation of parathyroid hormone receptors on umr 106-01 osteoblastic osteosarcoma cells. Endocrinology 1991; 129: 2547-54.

34. Woodard JC, Webster PD, Carr AA. Primary hypomagnesemia with secondary hypocalcemia, diarrhea and insensitivity to parathyroid hormone. Am J Dig Dis 1972; 17: 612-8.

35. Iwasaki Y, Asai M, Yoshida M, Oiso Y, Hashimoto $K$. Impaired parathyroid hormone response to hypocalcemic stimuli in a patient with hypomagnesemic hypocalcemia. J Endocrinol Invest 2007; 30: 513-6.

36. Mortensen L, Hyldstrup L, Charles P. Effect of vitamin D treatment in hypoparathyroid patients: a study on calcium, phosphate and magnesium homeostasis. Eur J Endocrinol 1997; 136: 52-60.

37. Weinman EJ, Biswas RS, Peng G, et al. Parathyroid hormone inhibits renal phosphate transport by 
phosphorylation of serine 77 of sodium-hydrogen exchanger regulatory factor-1. J Clin Invest 2007; 117: 3412-20.

38. Koura HM, Ismail NA, Kamel AF, Ahmed AM, Saad-Hussein A, Effat LK. A long-term study of bone mineral density in patients with phenylketonuria under diet therapy. Arch Med Sci 2011; 7: 493-500.

39. De Franceschi L, Bachir D, Galacteros F, et al. Oral magnesium supplements reduce erythrocyte dehydration in patients with sickle cell disease. J Clin Invest 1997; 100: $1847-52$. 